\title{
LEGAL REGULATION OF SURROGACY AT THE INTERNATIONAL AND NATIONAL LEVELS: OPTIMIZATION OF PERMISSIONS, PROHIBITIONS AND LIABILITY
}

DOI: 10.36740/WLek202012229

\author{
Oksana M. Ponomarenko', Yuriy A. Ponomarenko ${ }^{2}$, Kateryna Yu. Ponomarenko ${ }^{3}$ \\ ${ }^{1}$ H. S. SKOVORODA KHARKIV NATIONAL PEDAGOGICAL UNIVERSITY, KHARKIV, UKRAINE \\ ${ }^{2}$ YAROSLAV MUDRYI NATIONAL LAW UNIVERSITY, KHARKIV, UKRAINE \\ ${ }^{3}$ NATIONAL AEROSPACE UNIVERSITY - KHARKIV AVIATION INSTITUTE, KHARKIV, UKRAINE
}

\begin{abstract}
The aim: To identify the issues that arise in states that consolidate different approaches to the use of surrogacy technologies and formulate the main trends towards unification of legislation in this area.

Materials and methods: The study used a complex of general scientific and special methods of cognition, in particular, dialectical, generalizing, comparative legal and others. The research is based on the national and international legislation of different countries, the jurisprudence of national courts and the practice of the ECHR, doctrinal research by scientists from different countries.

Conclusions: The development of an international legal document which aim is to protect the rights of children born with the use of surrogacy technology is substantiated on the basis of the main principle enshrined in paragraph 1 of Art. 3 of the Convention on the Rights of the Child - the principle of the best interests of the child.
\end{abstract}

KEY WORDS: surrogacy, assisted reproductive technologies, the origin of the child, contractual regulation of family relations, cross-border criminal liability

Wiad Lek. 2020;73(12 p. II):2877-2881

\section{INTRODUCTION}

The first child using surrogacy technology was born 40 years ago by fertilizing the surrogate's egg with the customer's sperm (traditional surrogacy). Since then, the use of surrogacy technology in the world has become quite popular in solving the problems of childlessness. Traditional surrogate motherhood, in which a surrogate mother is genetically related to a child, is now almost never resorted to, although it is still allowed in the laws of some states. In modern medicine, usually gestational surrogacy is used, in which the surrogate mother is not biologically related to the child. That is why it is believed that gestational surrogacy is more benign for a surrogate mother. The presence of a biological connection between a child and one (or both) potential parents favorably distinguishes surrogate motherhood from adoption, in which usually a biologically alien child is adopted, and makes this way of solving the problems of combating childlessness for prospective parents a higher priority.

And despite the fact that a lot of time has passed since the first experience of using surrogacy, the attitude towards this technology in society is not unambiguous. This is due to the fact that surrogate motherhood is not a purely medical problem, but affects the moral, ethical, religious aspects, in connection with which states have different attitudes towards its legal regulation.
In some countries, surrogacy is prohibited, in others it is allowed, in some states it is not regulated at all. It should be noted that no matter what approach to the legal regulation of surrogacy one or another country chooses, everyone has problems with its application and the consequences of its application. It is safe to say that surrogacy has become a common problem for all states and requires the development of a common concept for its regulation.

\section{THE AIM}

The purpose of this article is to study the national legislations of different states to identify problems associated with the use of surrogacy and to find ways to develop a general concept of its legal regulation at the international level.

\section{MATERIALS AND METHODS}

The research is based, firstly, on the study of the national legislation of a number of European states (Belarus, France, Germany, India, Russia, Ukraine, Switzerland, etc.), which provide various regimes of legal regulation of surrogacy as a reproductive technology. By means of a comparative analysis of their prescriptions, general and different provisions in such legal regulation have been identified, and the problems associated with cross-border recourse to 
surrogacy are shown. In addition, some decisions of the ECHR, which resolved the issue of the balance of human rights when using surrogacy technology, were studied. Finally, the materials of the judicial practice of individual states are also analyzed in terms of establishing the legal consequences of resorting to the technology under study.

\section{REVIEW AND DISCUSSION}

\section{ISSUES OF COUNTRIES WHICH LEGISLATION PROHIBITS SURROGATE MATERNITY.}

Many European countries prohibit the use of surrogacy technologies. The methods of prohibitions in such states differ: in some countries, such a prohibition is either directly contained in the Constitution or established by the courts, based on the interpretation of its more general provisions; in others, it is contained in civil law or established by special laws; thirdly, it is also supported by sanctions in the criminal law.

For example, in Germany courts, based on Part 1 of Art. 1 of the Constitution, which declares that "Human dignity shall be inviolable. To respect and protect it shall be the duty of all state authority" [1] and section 1591 of the German Civil Code [2], according to which "The mother of a child is the woman who gave birth to it", come to an unequivocal conclusion that surrogacy is prohibited [3].

At the same time, a special law was adopted in Switzerland: Federal Act on Medically Assisted Reproduction [4], which established that "Ovum and embryo donation and surrogate motherhood are prohibited" (art. 4). The principle of the monism of the criminal law is unknown to the Swiss criminal law. Therefore, it is not surprising that criminal liability for violation of this prohibition was established not in the Swiss Criminal Code, but in the same Federal Act on Medically Assisted Reproduction. Article 31 (as amended by Federal Act of 12.12.2014 [5]) provides that "Any person who uses an assisted reproductive technique in a surrogate mother shall be liable to a custodial sentence not exceeding three years or to a monetary penalty. The same penalty shall apply to any person who acts as an intermediary for surrogate motherhood".

However, despite the existing bans, residents of these states sometimes deliberately violate national legislation in order to solve the problem of childlessness. To do this, they apply for the use of surrogacy technology in those countries in which this technology is allowed at the legislative level. As a result, such parents in their country, and sometimes in the country to which they come to apply this procedure, have difficulties with legalizing their parental relations, and sometimes - problems associated with bringing them to justice, including criminal one [6]. As you know, the criminal legislation of many European countries proceeds in such cases from the so-called principle of "double wrongfulness", which consists in the fact that the possibility of criminal prosecution under the legislation of a particular country for a crime committed outside its borders is conditioned by the recognition of the act as criminal under the law of the place of its commission. For example, according to clause "a" part 1 of Art. 7 of the Criminal Code of Switzerland "Any person who commits a felony or misdemeanor abroad ... is subject to this Code if the offence is also liable to prosecution at the place of commission or the place of commission is not subject to criminal law jurisdiction" [7] Thus, referring to the technology of surrogacy, for example, on the territory of Ukraine (according to the legislation of which these actions are not criminal), a Swiss citizen or resident, even after returning to the jurisdiction of his state, cannot be held criminally liable.

In the EU countries many judges have come up with legal arrangements that grant a child born from a commercial gestational surrogacy legal parentage with its "intended parents" [8]. In particular, "In a number of States ad hoc, 'ex post facto' remedies have been found with a view to reducing the harmful impact of this legal limbo for children. These remedies are ways of trying to cope with situations which are, in effect, a fait accompli: the child is already born and usually the surrogate mother does not wish to care for the child and the intending parents do» [9].

An analysis of the practice of the ECHR allows us to name some of the response measures that such states apply in relation to their citizens who have violated the prohibition of national legislation on surrogacy. Such measures should, for example, include:

- refusal to guarantee legal recognition of a father-child relationship that was legally established in the state in which the surrogate mother gave birth to a child (Mennesson $v$. France [10] and Labassee v. France [11]);

- the authorities' refusal to grant permission to enter the territory of the state of a child who was born in another country from a surrogate mother until the intended parents provide sufficient evidence to confirm their family relationship with the child (D. and Others v. Belgium [12]); - taking away the child and transferring it for adoption (Paradisoi Campanelli v. Italy [13]);

- refusal of the authorities to register all information from the birth certificate of children born abroad in accordance with the agreement on gestational surrogacy ( $C$ and $E v$. France [14])

There have also been attempts in Italy to prosecute alleged parents for violating the ban on surrogacy. However, since Italian criminal law also recognizes the already mentioned so-called principle of "double wrongfulness", the court in this case dropped the charge on the grounds that the parents were not criminally responsible for the actions that are lawful in the territory of the state where they were committed [15, p. 6-7].

The application of such negative consequences to citizens who are forced to turn to medical institutions in other countries to fulfil their natural need for parenting naturally causes their discontent. They reasonably believe that by such actions states violate their right to respect for private and family life guaranteed by Art. 8 EConvHR, States, on the other hand, justify the possibility of applying negative consequences to alleged parents by actions in the public 
interest in order to protect health or morality, protect the rights and freedoms of others. Thus, for example, in Mennesson v. France and Labassee v. France The Court noted that the State intervention had two legitimate aims, as defined in Art. 8, namely "health protection" and "protection of the rights and freedoms of others". The court also found that the refusal of the French authorities to recognize the legal relationship between children born as a result of surrogacy technology stems from the desire to prevent French citizens from seeking help outside of France for reproductive technology, which is prohibited in that country in order to protect children and a surrogate mother.

Thus, in regulating relations on the use of surrogacy technologies and their consequences, it is necessary to try to maintain a fair balance between private and public interests, in which the ECHR plays an important role. It should be noted that when resolving disputes related to the use of surrogacy technologies, the ECHR most often makes decisions in favor of the intended parents. Thus, in Mennesson v. France The Court stressed that states should be left with wide boundaries in the choice of decision-making related to surrogacy, given the complex ethical issues and lack of consensus on these issues in Europe. However, these choices are narrow when it comes to parenthood, in which a key aspect of individuals' identity has been involved. The Court had to find out whether a fair balance had been struck between the interests of the State and the immediate interests of persons, with particular emphasis on the fundamental principle that, whenever children are affected, their interests should prevail.

However, in Paradiso and Campanelli v. Italy The ECtHR dismissed the applicants' complaint and recognized the actions of the Italian authorities as legitimate, pursuing legitimate aims to counteract violations and aimed at protecting the rights and freedoms of others. The main argument in this case was the lack of a biological connection between potential parents and a child born to a surrogate mother. And despite the fact that the reason for this was the mistake of the medical institution, whose services the potential parents turned to, the court considered that the implementation of the exclusive powers of the state to recognize the legal parent-child relationship is possible only in the case of biological connection or adoption. Thus, the removal of the child and the transfer of him for adoption was recognized as legal.

All of the above allows us to conclude that in countries where surrogate motherhood is prohibited, there is a need to think about the possible reform of legislation and regulatory regulation of the registration process of potential parents' parental rights in relation to a child born by a surrogate mother in another state.

\section{ISSUES OF COUNTRIES WHICH LEGISLATION ALLOWS SURROGATE MOTHERHOOD.}

Surrogacy is allowed in Belarus, Great Britain, Georgia, Russia, USA, Ukraine and other countries. The laws of these states regulate the use of this technology in different ways.
In some countries, only altruistic surrogacy is allowed, in which the surrogate mother does not receive remuneration for bearing and giving birth to a child, but is only entitled to compensation for losses and costs associated with surrogacy. In other countries, commercial surrogacy is allowed. It is the latter that become a refuge for childless people who come there for the purpose of bearing and giving birth to a child for them by a surrogate mother. It is worth noting that the services of surrogate mothers from such countries are used not only by childless couples from states where surrogacy is prohibited, but also by citizens of those countries where the use of this technology is permitted, but associated with significant organizational and financial difficulties. So, statistically about half of all U.K. surrogacy contracts involve overseas surrogates - many of them in locations (like California) where commercial surrogacy contracts are enforceable [16, p. 7].

It should be noted that many of the countries that allow commercial surrogacy are emerging economies. The incomes of citizens of such countries are quite low, and women are forced to accept the role of a surrogate mother in order to earn money. Many researchers note that commercial surrogacy in economically underdeveloped countries is a form of exploitation of women [17, p. 12].

The governments of some countries, which have become the center of reproductive tourism, are forced to respond to abuses in this area in the most radical way. So, in 2012, about 10,000 foreign clients visited India to provide reproductive services; almost $30 \%$ of them were either single or homosexual. After ten years of commercial surrogacy, India has finally banned commercial surrogacy for foreigners [18]. The ban was based on Ms Jayarshi Wad's lawsuit in the New Delhi Supreme Court, in which she argued that surrogacy was a violation of women's rights to life and liberty. Commercial surrogacy for foreign citizens was also prohibited in other countries, that used to be the "surrogacy havens", due to all the ethical and moral questions arising from commercial surrogacy and the inherent risk of human rights violations» $[19, \mathrm{p} .17])$.

After the introduction of a ban on commercial surrogacy in India, as well as in Thailand, Nepal and Cambodia, the center of transnational reproductive tourism shifted to the countries of Eastern Europe, the leaders of which in this area are Russia, Ukraine, Belarus, Georgia. The lack of state control over the conclusion of agreements on surrogacy and the use of this technology is the reason for the lack of statistics on the number of children born to surrogate mothers. The scope of this procedure, for example, in Ukraine and Russia, was revealed only when journalists discovered dozens of babies born to surrogate mothers, whom their biological parents could not pick up due to the closure of state borders during the quarantine period caused by the coronavirus pandemic (COVID-19) [20;21] .

The next problem faced by countries that allow surrogacy is to find an answer to the question: whose rights are in priority - a surrogate mother or potential parents? And related questions: how is parental rights transferred from a surrogate mother to potential parents (in the event that parental rights 
initially arise for the surrogate mother and her spouse)? Is it possible to enforce a surrogacy agreement if the surrogate mother refuses to voluntarily transfer the child or rights to it? Countries that allow surrogacy deal with these issues in different ways in their national legislation.

So, for example, in accordance with Part 4 of Art. 51 of the RF FC, persons who are married and have given their written consent to implantation of an embryo to another woman for the purpose of carrying it, can be registered by the child's parents only with the consent of the surrogate mother. In the judicial practice of the Russian Federation, there are several high-profile cases related to the refusal of a surrogate mother to give consent to the transfer of a child to biological parents [22]. The priority of the rights of a surrogate mother in relation to the rights of potential parents is also sharply criticized by judge of the Constitutional Court of Russian Federation S.D. Knyazev: "The purpose of surrogacy as a method of treating infertility is to provide a married man and woman, who are unable to independently realize their reproductive rights, the ability to become parents of their genetic child. In this regard, the question inevitably arises of whether the option of legal regulation chosen by the legislator, which removes, according to many experts, in the interests of children even the potential for disputes over the rights to a child between a surrogate mother and genetic parents, corresponds to the purpose of the institution of surrogate motherhood" [23].

The opposite approach is laid down in the family legislation of Ukraine and Belarus which enshrines the presumption according to which the parents of a child born by a surrogate mother are the customers (Art. 123 of the FK of Ukraine [24], Art. 52 of the Code of the Republic of Belarus on Marriage and Family [25]). This approach makes these countries very attractive for transnational reproductive tourism, since the priority of the rights of potential parents is enshrined in the legislation of these countries.

It should be noted that art. 21 of the Law of the Republic of Belarus "On Assisted Reproductive Technologies" [26] regulates in sufficient detail the issues related to the use of surrogacy. Particularly noteworthy is the fact that the legislator fixes the essential terms of the contract and the rights and obligations of a surrogate mother.

Allowing only altruistic motherhood significantly limits the use of this technology. Usually, in this case a relative or a good acquaintance of the family becomes a surrogate mother for the intended parents, who, out of the kindness of her heart, agreed to bear a child for a childless couple. And despite the fact that with altruistic surrogate motherhood, it is difficult to reproach the exploitation of a surrogate mother who is forced to agree to bear someone else's child in order to earn money, many issues still arise.

\section{GENERAL ISSUES THAT ARISE IN THE LEGAL REGULATION OF THE APPLICATION OF TECHNOLOGIES OF SURROGATE MATERNITY AND THE TRENDS OF THEIR SOLUTION.}

The issues that were faced by national governments and the ECHR in the field of surrogacy technologies have caused concern at the highest international level. As a result, these issues are being actively discussed at various international platforms in order to develop common guidelines and approaches in the legal regulation of surrogacy. For example, since 2011, the Permanent Bureau of the Hague Convention on Private International Law has been studying issues of private international law, including issues arising in the context of international agreements on surrogacy. In 2018, several UN agencies organized an inter-agency meeting on surrogacy and human rights in Bangkok. In June 2019, during the 74th session of the UN General Assembly, the Special Rapporteur on the sale and sexual exploitation of children, including child prostitution, child pornography and other child sexual abuse material, presented a report on the protection of the rights of children born from surrogacy arrangements.

Based on a study of the practice of surrogate motherhood using, national legislative regulation, and judicial practice, she identified issues and provided recommendations for improving national legislation in order to comply with the minimum guarantees of the rights of children born to surrogate mothers. It also proposed to consider the possibility of developing a model law based on the available scientific evidence and good practice on the application of the principle of the child's best interests by states in the context of domestic law and public international law governing international and transnational surrogacy procedures [27]

\section{CONCLUSIONS}

It seems that the development of an international document aimed at protecting the rights of children born with the use of surrogate motherhood technology is the only possible way to solve the issues that arise in this area. Unification of legal regulation in the field of application of surrogacy technologies should be carried out on the basis of the main principle enshrined in paragraph 1 of Art. 3 of the Convention on the Rights of the Child - the principle of the best interests of the child. In this paradigm, national legislation should also develop, regardless of whether the use of surrogacy technology is allowed or prohibited in the state. Particular attention in acts dedicated to the regulation of surrogacy should be paid to finding the optimal balance between the interests of the surrogate mother and potential parents. It is also necessary to develop a system for monitoring the use of surrogacy technology at the international and national levels. This will minimize violations and abuses in this area.

\section{REFERENCES}

1. Grundgesetz für die Bundesrepublik Deutschland. Available from: http:// www.gesetze-im-internet.de/gg/GG.pdf [reviewed 2020.10.10].

2. Bürgerliches Gesetzbuch (BGB). Available from: https://www.gesetze-iminternet.de/bgb/BGB.pdf [reviewed 2020.10.10].

3. Surrogate motherhood: a violation of human rights. Report presented at the Council of Europe, Strasbourg, on 26 april 2012. Available from: https://www.ieb-eib.org/ancien-site/pdf/surrogacy-motherhood-icjl. pdf [reviewed 2020.10.10]. 
4. Federal Act on Medically Assisted Reproduction of 18 December 1998. Available from: https://www.admin.ch/opc/en/classified-compilati on/20001938/201709010000/810.11.pdf [reviewed 2020.10.10].

5. Bundesgesetz über die medizinisch unterstützte Fortpflanzung (Fortpflanzungsmedizingesetz, FMedG) Änderung vom 12. Dezember 2014. Available from: https://www.admin.ch/opc/de/officialcompilation/2017/3641.pdf [reviewed 2020.10.10].

6. Valentyna I. Borysova, Kseniia Yu. Ivanova, Larysa V. Krasytska. Problems Of Assisted Reproductive Technology's Application. Wiadomości Lekarskie 2019;Tom LXXII (12);Cz. II:2524-2530 doi: 10.36740/ WLek201912221.

7. Swiss Criminal Code of 21 December 1937 (Status as of 1 July 2020) . Available from: https://www.admin.ch/opc/en/classified-compilatio n/19370083/202007010000/311.0.pdf [reviewed 2020.10.10].

8. Rechtliche Mutterschaft der Leihmutter bei Anwendung deutschen Rechts. Available from: http://juris.bundesgerichtshof.de/cgi-bin/ rechtsprechung/document.py?Gericht=bgh\&Art=pm\&Datum=2019$4 \& n r=94809 \& p o s=6 \& a n z=20$ [reviewed 2020.10.10].

9. Opinion of the reflection group on bioethics on gestational surrogacy the question of European and international rules. Available from: http://www.comece.eu/dl/nLpuJKJnmLLJqx4KJK/Surrogacy_EN_ WEB.pdf?fbclid=IwAR07LNixufY_m50GLi1nXXDJkICOM8u032N_ hlkMstu1JY3E1jLGQM-KcM [reviewed 2020.10.10].

10. Case of Mennesson v. France (Appl. no. 65192/11). Available from: http://hudoc.echr.coe.int/fre?i=001-145389 [reviewed 2020.10.10].

11. Affaire Labassee c. France (Requête no 65941/11). Available from: http://hudoc.echr.coe.int/eng?i=001-145180 [reviewed: 2020.10.10].

12. D. et autres contre la Belgique (Requête no 29176/13). Available from: http://hudoc.echr.coe.int/eng?i=001-146420 [reviewed:2020.10.10].

13. Questions and Answers on the Paradiso and Campanelli v. Italy judgment (27 January 2015). Available from: https://www.echr.coe.int/Documents/ Press_Q_A_Paradiso_and_Campanelli_ENG.pdf[reviewed:2020.10.10].

14. Decision C and E v. France. Available from: http://hudoc.echr.coe.int/ eng-press? i=003-6589814-8731890 [reviewed: 2020.10.10].

15. Claire Fenton-Glynn International surrogacy before the European Court of Human Rights. Journal of Private International Law. 2017;13:3, 546567, doi: 10.1080/17441048.2017.1385901.

16. Stephen R. Latham. The United Ringdom revisits its surrogacy law. Hastings center report. 2020. Available from: https://onlinelibrary. wiley.com/doi/epdf/10.1002/hast.1076 [reviewed: 2020.10.10].

17. Opinion of the reflection group on Bioethics on gestational surrogacy: the question of European and international rules, 2015:12 Available from: http://www.comece.eu/dl/nLpuJKJnmLLJqx4KJK/Surrogacy_ EN_WEB.pdf?fbclid=IwAR07LNixufY_m50GLi1nXXDJkICOM8u032N_ hlkMstu1JY3E1jLGQM-KcM [reviewed: 2020.10.10].

18. Sharmila Rudrappa. Reproducing Dystopia: The Politics of Transnational Surrogacy in India, 2002-2015. doi.org/10.1177\% 2F0896920517740616.

19. F. Redondo, F. Valente, M. Esteves, M. Perquilhas, Surrogacy: a clash of competing rights, 2017, p. 17. Available from: http://www.ejtn. eu/Documents Team\%20Portugal\%202\%20semi\%20final\%20B.pdf [reviewed: 2020.10.10].

20. 46 detej ot surrogatnyh materej «zastryali» v kievskoj gostinice. Ih ne mogut zabrat' iz Ukrainy iz-za karantina [46 children from surrogate mothers "stuck" in a Kyiv hotel. They cannot be taken from Ukraine due to quarantine]. Availablefrom:https://tk.media/news/46-detey-ot-surrogatnyh-matereyzastryali-v-kievskoy-gostinitse-ih-ne-mogut-zabrat-iz-ukrainy-iz-zakarantina-2020-05-14 [reviewed: 2020.10.10] (Ru).
21. Tysyacha detej inostrancev ot surrogatnyh materej zastryali v Rossii iz-za pandemii [A thousand children of foreigners from surrogate mothers are stuck in Russia due to the pandemic.]. Available from: https://lenta. ru/news/2020/07/30/surrogate/ [reviewed: 2020.10.10] (Ru).

22. Dmitrieva A. Sud'i ne prishli k edinomu mneniyu, kak sleduet registrirovat' rodivshihsya ot surrogatnoj materi detej [The judges did not come to a consensus on how to register children born from a surrogate mother]. Available from: http://www.garant.ru/ article/1273537/\#ixzz6bEL7uq5x [reviewed: 2020.10.10] (Ru).

23. Mnenie sud'i Konstitucionnogo Suda RF S. D. Knyazeva [The opinion of the judge of the Constitutional Court of the Russian Federation S.D. Knyazev]. Available from: http://www.consultant.ru/document/cons doc_LAW_131275/07597ea219c3e5c348363de82c2d9263a69ae02f/ [reviewed: 2020.10.10] (Ru).

24. Simejnij kodeks Ukrainy : Zakon Ukrainy № 2947-III [Family Code of Ukraine: the law of Ukraine]. Available from: https://zakon.rada.gov. ua/laws/show/2947-14\#Text [reviewed: 2020.10.10] (Ua).

25. Kodeks Respubliki Belarus' «0 brake i sem'e» [Code of the Republic of Belarus "On marriage and family"]. Available from: https://online. zakon.kz/document/?doc_id=30414964 [reviewed:2020.10.10] (Ru).

26. Zakon Respubliki Belarus' "0 vspomogatel'nyh reproduktivnyh tekhnologiyah" [Law of the Republic of Belarus "On Assisted Reproductive Technologies"]. Available from: https://kodeksy-by.com/ zakon_rb_0_vspomogatel_nyh_reproduktivnyh_tehnologiyah.htm. [reviewed: 2020.10.10] (Ru).

27. Report of the Special Rapporteur on the sale and sexual exploitation of children, including child prostitution, child pornography and other child sexual abuse material. Available from: https://undocs.org/en/A/74/162 [reviewed: 2020.10.10].

\section{ORCID and contributionships:}

Oksana M. Ponomarenko: 0000-0001-6394-1834 ${ }^{D}$

Yuriy A. Ponomarenko: 0000-0002-1030-1072 ${ }^{A, E}$

Kateryna Yu. Ponomarenko: 0000-0001-5133-5036 B,F

\section{Conflict of interest:}

The Authors declare no conflict of interest.

\section{CORRESPONDING AUTHOR} Oksana M. Ponomarenko

H. S. Skovoroda Kharkiv National Pedagogical University, Kharkiv, Ukraine

tel: +380973325570

email: ponomarenkooksana1976@gmail.com

Received: 28.08 .2020

Accepted: 30.11 .2020

A - Work concept and design, B - Data collection and analysis, C - Responsibility for statistical analysis, D-Writing the article, E-Critical review, $\mathbf{F}$ - Final approval of the article 